\title{
Synthesis, Characterization and Ecotoxicity Evaluation of Biochar-Derived Carbon Dots from Spruce Tree, Purple Moor-Grass and African Oil Palm
}

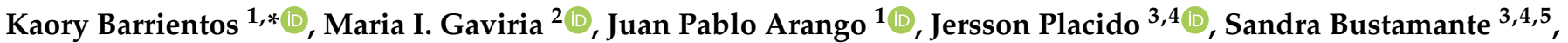 \\ Martha E. Londoño ${ }^{1}$ and Marisol Jaramillo ${ }^{1}$
}

1 GIBEC Research Group, Life Sciences Faculty, Universidad EIA, Calle 25 Sur \#42-73, Medellín 055420, Colombia; juan.arango45@eia.edu.co (J.P.A.); marta.londono@eia.edu.co (M.E.L.); marisol.jaramillo@eia.edu.co (M.J.)

2 GDCON Research Group, Engineering Faculty, Universidad de Antioquia, Calle 67 No. 53-108, Medellín 050010, Colombia; mariai.gaviria@udea.edu.co

3 Institute of Life Science, Swansea University Medical School, Singleton Park, Swansea SA2 8PP, Wales, UK; jersson.placido@vedascii.org (J.P.); sandra.bustamante@vedascii.org (S.B.)

4 VEDAS Corporación de Investigación e Innovación (VEDAS CII), Cl 8 B 65-261, Medellín 050024, Colombia

5 Centre for NanoHealth, Department of Physics, Swansea University, Swansea SA2 8PP, Wales, UK

* Correspondence: kaory.barrientos@eia.edu.co

check for updates

Citation: Barrientos, K.; Gaviria, M.I.; Arango, J.P.; Placido, J.; Bustamante, S.; Londoño, M.E.; Jaramillo, M. Synthesis,

Characterization and Ecotoxicity Evaluation of Biochar-Derived Carbon Dots from Spruce Tree, Purple Moor-Grass and African Oil Palm. Processes 2021, 9, 1095. https://doi.org/10.3390/pr9071095

Academic Editor: Enrico Marsili

Received: 27 May 2021

Accepted: 10 June 2021

Published: 24 June 2021

Publisher's Note: MDPI stays neutral with regard to jurisdictional claims in published maps and institutional affiliations.

Copyright: (c) 2021 by the authors. Licensee MDPI, Basel, Switzerland. This article is an open access article distributed under the terms and conditions of the Creative Commons Attribution (CC BY) license (https:/ / creativecommons.org/licenses/by/ $4.0 /)$.

\begin{abstract}
Biochar-derived C-Dots from Picea, Molinia caerulea and Elaeis guineensis were synthesized through a hydrothermal process, and their physicochemical and optical characteristics and environmental effects were compared. These C-Dots were characterized by techniques such as Attenuated Total Reflection-Fourier Transform Infrared (ATR-FTIR), UV-Vis spectrophotometry, fluorescence spectroscopy, dynamic light scattering (DLS), Z potential, and High-Resolution Transmission Electronical Microscopy (HR-TEM). The ecotoxicity tests were performed using the Microtox ${ }^{\mathrm{TM}}$ test, making this study one of the few that use this method. The C-Dots from Molinia caerulea showed the best quantum yield (QY) of $8.39 \%$ and moderate ecotoxicity, while Elaeis guineensis has the lowest QY (2.31\%) but with zero toxicity. Furthermore, the C-Dots from Picea presents good optical properties but showed high toxicity and limits its use. Finally, all C-Dots showed functional groups that could be biofunctionalized with biomolecules, especially C-Dots from Molinia caerulea and Elaeis guineensis show potential for use in the development of optical biosensors.
\end{abstract}

Keywords: biochar; carbon dots; nanoparticle; fluorescence; ecotoxicity

\section{Introduction}

Non-pollutant energy access is one of the sustainable development goals defined by the United Nations (UN) to achieve sustainability by 2030 [1], so many research efforts have been focused mainly on the use of plant biomass for energy and biofuels production from high temperature deconstructive methods such as pyrolysis, gasification, and thermal liquefaction [2-5]. Pyrolysis is a method with complete absence of oxygen and process temperatures around $300-700{ }^{\circ} \mathrm{C}$. The three main products from pyrolysis are synthesis gas (syngas), bio-oils, and biochar [6]. Syngas and bio-oils are widely used for electricity, heat, and biofuel production while biochar is used in bioremediation and amendments processes in soils [6-8]. However, the use of biochar is limited due to the variability of the physicochemical properties that depend on the original biomass and the thermal process conditions. Therefore, alternatives for the use of biochar are necessary for the integral sustainability of the pyrolysis process and to close biological cycles following circular economy principles $[9,10]$.

Biochar from the pyrolysis process usually exhibits a porous and semi-crystalline structure with a large surface area. This kind of structure maintains the surface chemical 
groups (aromatics and negative charge groups), the mineral compounds and give it biological resistance [11,12]. Those characteristics make the biochar a good precursor for more add-value carbonaceous materials, like C-Dots [12-14]. Recently, the interest on synthesis strategies for nanomaterials is growing, using waste biomass and biochar [15-18].

Carbon dots (C-Dots) are quasi-spherical nanoparticles that are made mainly from carbon and oxygen, usually with sizes below $10 \mathrm{~nm}$ [19-22]. These nanomaterials have gained attention because of their excellent photoluminescence yields and high photostability, which make them comparable to traditional quantum dots, but less toxic for biological systems $[19,23,24]$. C-Dots are attractive for their application as fluorescent probes for bioimaging [25,26], drug delivery [27-29], and optical biosensors development for environmental [30,31], agroindustry [32,33], and public health [34-37], with detection limits on nM order [38-40]. The obtention of different types of C-Dots depends on the original feedstock, the physicochemical characteristics of the feedstock, synthesis conditions [23] and the doping with heteroatoms and surface modifications [41]. Therefore, the characterization of the feedstock and the synthesized C-Dots is necessary. Currently, C-Dots synthesis includes methods like laser ablation, arc discharge, solvothermal oxidation, hydrothermal treatment, and microwave irradiation. Combining some of these methods like hydrothermal treatment with natural sources or waste materials, like biochar, becomes an excellent strategy for cost reduction, continuous precursor supply and the obtention of low toxicity nanomaterials [16]. Biochar has been employed as a precursor for C-dots production by different authors and different feedstocks such as sugar cane bagasse [42], microalgae biomass [21], flowers waste, ornamentals plants and fruits $[15,43]$.

Besides, the toxicity studies of nanomaterials like C-Dots are significant areas of research since there is a wide debate about the possible risks associated with the widespread use of nanomaterials $[44,45]$. These risks are correlated with their size, shape, and chemical characteristics that can interact with biological systems causing a blockage of some signaling routes [46]. Although the study of toxicology effect of C-dots related to human health is more widespread, the effects of these particles in the environment, especially in aquatic environments are less evaluated and are fundamental to determine the impact of these nanoparticles on water quality, and their effect on the biodiversity of aquatic ecosystems [47-50].

The aim of this article was to compare the physicochemical and optical characteristics and the environmental effects of biochar-derived C-Dots from three different feedstocks: spruce tree (Picea), purple moor-grass (Molinia caerulea), and African oil palm (Elaeis guineensis). The biochar from Picea and Molinia caerulea was donated by two welsh companies that produced biochar from two highly produced biomasses in Wales. However, the feedstock of Elaeis guineensis was selected because it was intended to use materials available in Colombia to be part of the bioeconomy process. Colombia is the fourth producer of palm oil in the world and the first in America, which makes it generate annually about 400,000 tons of waste (approximately 2\% of world production), to which must be added value to contribute to the closing of cycles. The C-Dots were obtained through a hydrothermal method and their chemical structure, toxicity, and stability were characterized through different techniques like FTIR, UV-Vis, Fluorescence spectrophotometry, Z potential, DLS, TEM and ecotoxicity.

\section{Materials and Methods}

\subsection{Reagents}

Three types of biochar were evaluated in this research, purple moor grass-biochar (Molinia caerulea), spruce tree-biochar (Picea), and African oil palm-biochar (Elaeis guineensis). Purple moor grass-biochar was kindly donated by Henfron Farm (Elan Valley, LD6 5HE, UK) and it was prepared with an Exeter Biocharcoal Retort (Carbon Compost Ltd.; Exeter, UK) in pyrolysis mode and temperatures between $300{ }^{\circ} \mathrm{C}$ and $375{ }^{\circ} \mathrm{C}$ for $4 \mathrm{~h}$. Spruce treebiochar was kindly provided by Common Visions LTD (Swansea, Wales, UK). African oil palm-biochar was kindly donated by the "Grupo de Investigación de Energías Alternativas- 
Centro de Desarrollo Tecnológico del Carbón" research group (GEAB-CIDTEC) from the Universidad Popular del Cesar, UPC Colombia. African oil palm-biochar was prepared at the "Centro Corporación de Investigación de la Palma de Aceite-Cenipalma" and the process involves the pyrolysis of oil palm trunk using FAO (Food and Agriculture Organization of the United Nations) technology and temperatures between $200{ }^{\circ} \mathrm{C}$ and $400{ }^{\circ} \mathrm{C}$ [51]. All biochar were conserved at room conditions until use. Ultrapure water system (Barnstead Smart2Pure, Thermo Scientific, Pittsburg, CA, USA) was used through all the experimental setting. Acetone and potassium permanganate $\left(\mathrm{KMnO}_{4}\right)$ were bought from Merck Millipore (Burlington, VT, USA). All chemicals were analytical grade.

\subsection{Biochar Characterization}

African oil palm-biochar and purple moor grass-biochar were characterized by "Grupo interdisciplinario de estudios moleculares" research group (GIEM) from Universidad de Antioquia. The characterization process followed the guide given in the standards NTC 5167 for $\mathrm{pH}$ and ashes measurement, NTC 370 for total organic Nitrogen measurement and AOAC 98002 for sulfur measurement. Other characteristics of the oil pam-biochar and purple moor grass-biochar could be consulted in Supplementary Material. The identification of biochar functional groups was performed through Attenuated Total Reflection-Fourier Transform Infrared (ATR-FTIR) in a Perkin Elmer (Waltham, MA, USA) instrument between $3000 \mathrm{~cm}^{-1}$ and $650 \mathrm{~cm}^{-1}$ frequency range and 32 running scans at a resolution of $4 \mathrm{~cm}^{-1}$.

\subsection{Synthesis of Biochar-Derived C-Dots}

Biochar-derived C-Dots were synthesized using previously reported methods by Placido et al. $[13,21]$ employing a hydrothermal method in presence of a strong oxidation reagent $\left(\mathrm{KMnO}_{4}\right)$. First, the biochar was shattered into small pieces using a mortar and then passed through a $425 \mu \mathrm{m}$ sieve (Woven Wire, Endecotts), the sieved biochar was used for the C-dots production. The depolymerization reaction was performed with $10 \mathrm{~g}$ of biochar mixed with a solution of $\mathrm{KMnO}_{4} 10 \%(w / v)$ in a $500 \mathrm{~mL}$ Erlenmeyer flask. The depolymerization reaction was carried on an autoclave (SA-300H, Sturdy, Wilmington, DE, USA) at $121^{\circ} \mathrm{C}$ and 15 psi for $60 \mathrm{~min}$. After reaction, the biochar solutions were centrifuged (SL 8, Thermo Scientific) for $5 \mathrm{~min}$ at $1000 \mathrm{rpm}$ to separate the liquid (supernatant) and solid phases (remaining biochar). The supernatant was filtered with a $0.22 \mu \mathrm{m}$ syringe filter (Merck Millipore, Burlington, VT, USA). The filtered liquid was mixed with Acetone and centrifugated (SL 8, Thermo Scientific) again (1000 rpm, $5 \mathrm{~min}$ ) until the production of two liquid phases. The upper liquid phase was withdrawn, and later roto evaporated (BM500, Yamato, Santa Clara, CA, USA) at $85^{\circ} \mathrm{C}$ and $750 \mathrm{HPa}$. The Carbon-dots were purified by using overnight dialysis (3.5 KDa MWCO, Standard RC Dry Dialysis, Labs Spectra/PorTM 3) and freeze-dried (18LC-16WW-TS, Thermo Scientific) for $32 \mathrm{~h}$. The newly synthesized C-Dots were kept in solid state at $4{ }^{\circ} \mathrm{C}$ until use.

\subsection{Characterization of Biochar-Derived C-Dots}

C-Dots were characterized by various spectroscopic and morphological techniques. The fluorescence emission and excitation spectra and the UV-Vis spectra were performed at C-Dots concentration of 500 ppm in a Varioskan Lux (Thermo scientific, SkanIt Software 4.1) on a $200 \mu \mathrm{L}$ working volume microplates (Falcon ${ }^{\mathrm{TM}}$ non-treated black 96-well) and $20{ }^{\circ} \mathrm{C}$ with $1 \mathrm{~nm}$ optical step. The identification of C-Dots functional groups was performed through Attenuated Total Reflection-Fourier Transform Infrared (ATR-FTIR) in a Perkin Elmer instrument between $4000 \mathrm{~cm}^{-1}$ and $650 \mathrm{~cm}^{-1}$ frequency range and 32 running scans at a resolution of $4 \mathrm{~cm}^{-1}$. The stability of the synthesized C-Dots at a concentration of 1000 ppm was examined through Dynamic light scattering (DLS) and Z potential techniques on a Nanoplus-3. The measurement was performed using $0.2 \mu \mathrm{m}$ filtered solutions in a B0631009 cell, with water as a dispersant (Refractive Index: 1.3328). The shape and size of the C-Dots were taken using High-Resolution Transmission Electronical Microscopy (HR-TEM) on a FEI-Tecnai F20 Super Twin TMP. 


\subsection{Quantum Yield Measurement}

The quantum yield (QY) of the synthesized C-Dots was calculated through comparative method, using quinine sulfate in $0.5 \mathrm{M} \mathrm{H}_{2} \mathrm{SO}_{4}$ and based on previous reports $[15,16]$. The QY was calculated according to the following equation:

$$
Y=Q Y_{\text {ref }}\left(I_{\text {sam }} / I_{\text {ref }}\right) *\left(A_{\text {ref }} / A_{\text {sam }}\right) *\left(n_{\text {sam }}^{2} / n_{\text {ref }}^{2}\right)
$$

where suffix "ref" and "sam" refers to the standard reference and sample, respectively. "I" is the integrated fluorescent emission intensity, " $n$ " is the refractive index of the solvent and " $\mathrm{A}$ " is the intensity of absorbance. All the measurements were done at maximum intensity.

\subsection{Ecotoxicity Assay}

The C-Dots aquatic toxicity was evaluated via an ecotoxicity assay performed on a Microtox ${ }^{\mathrm{TM}}$ Model 500 Analyzer. The Microtox ${ }^{\mathrm{TM}}$ test is based on the measurement of Vibrio fischeri bioluminescence changes which correspond to cell viability, specifically the toxicity is related to fluorescence inhibition of the bacteria [52]. An 81.9\% Basic Test with 9 double dilutions was applied, starting from the concentration of $1000 \mathrm{ppm}$ for all the C-Dots samples. The results were calculated, taking into account the Gamma function after 5 and $15 \mathrm{~min}$, and were reported as EC50, that is, the concentration that causes the 50\% inhibition of the fluorescence of the microorganism [53]. Gamma [54] as:

$$
\text { Gamma }=\left(I_{c} / I_{t}\right)-1
$$

where $I_{c}$ is the average light reading of filtrates of the control solutions and $I_{t}$ is the light reading of a filtrate of a particular concentration of the test material.

\section{Results and Discussion}

\subsection{Biochar Characterization}

The characteristics of the three types of biochar are shown in Table 1. All materials have alkaline $\mathrm{pH}$, a characteristic attributed to the thermal decomposition of hydroxyl bonds and other weak bonds within the biochar structure produced under medium to high temperatures of synthesis [55]. The biochars exhibited variable nitrogen $(\mathrm{N})$ and sulfur (S) content, which is related to the initial content of the source and the temperature of the synthesis process. It has been reported that with increasing temperatures, more $\mathrm{N}$ and $\mathrm{S}$ were lost in the material [56,57]. The loss of $\mathrm{N}$ in the biochars was attributed to the removal of $\mathrm{N}$ via volatilization at relatively low temperatures $\left(\sim 200^{\circ} \mathrm{C}\right)$ [57]. Some works suggest that the pyrolysis temperature is an important factor that influences the speciation of sulfur in the biochar, since there is a much higher fraction of sulfur in organosulfur form for biochar produced at high temperatures, while the biochars at lower temperatures have sulfate, organosulfur, and sulfide $[56,58]$.

Table 1. Physicochemical characteristics of biochar.

\begin{tabular}{cccc}
\hline Parameter & Picea & Molinia caerulea & Elaeis guineensis \\
\hline $\mathrm{pH}$ & 8.9 & 9.58 & 8.26 \\
\hline$\%$ N (total organic) & 0.29 & 3.42 & 0.2 \\
\hline$\%$ S (total) & 0.43 & 1.46 & 1.5 \\
\hline$\%$ Ash & - & 6.80 & 11.1 \\
\hline Source & {$[59]$} & This work & This work \\
\hline
\end{tabular}

Among the analyzed materials, Molinia's biochar has the highest organic nitrogen content, while the biochar of Molinia caerulea and Elaeis guineensis have the highest sulfur content. Nitrogen values for biochar from Picea and Elaeis guineensis are comparable with 
those reported for biochar obtained from dairy manure [60], hardwood [61], eucalypt [62], willow [63-65], and bagasse from 14 agriculture waste [66]. The three materials reported in this study stand out for having a higher amount of sulfur than some of those reported in the literature [67].

The $\mathrm{N}$ and $\mathrm{S}$ content is important because these heteroatoms are associated with aromatic rings forming various functional groups on the biochar surfaces [55,68], which influences the properties of the material and its different applications [67,69]. Specifically, in the production of C-Dots from biochar, the $\mathrm{N}$ and $\mathrm{S}$ heteroatoms can be manipulated to act as electron donors or acceptors, and this process affects the characteristics and optical properties of the C-Dots that are obtained [70].

For the determination of the presence of functional groups on the biochar surface and the C-Dots, the Fourier transform infrared spectroscopy (FTIR) was used. The biochars FTIR spectrum of biochar derived from Picea, Molinia caerulea and Elaeis guineensis (Figure 1) doesn't show peaks with high intensities, which is supported by several authors [71-74], and it's due to the pyrolysis process, which is performed in biomass to produce biochar, because it promotes the rupture of several functional groups and the progressive carbonization of the material. However, all the spectra showed similar peaks at 744, 813, 877, 1574, and $1700 \mathrm{~cm}^{-1}$.

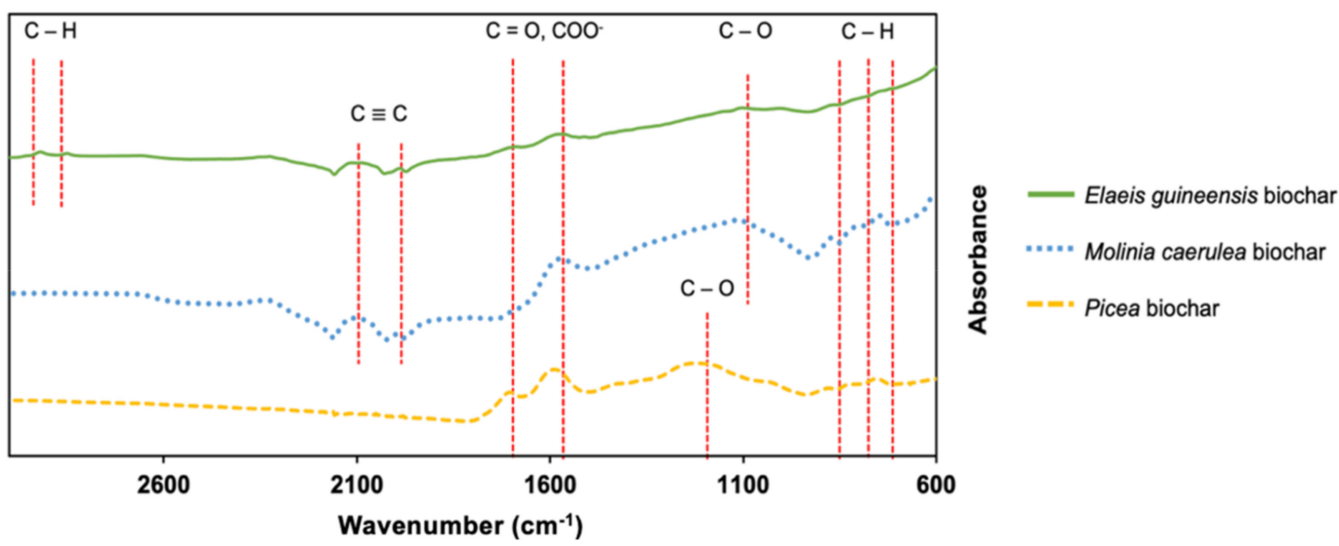

Figure 1. Picea, Molinia caerulea and Elaeis guineensis biochar FTIR spectra.

The peaks at 744,813 , and $877 \mathrm{~cm}^{-1}$ are associated with the carbon linkages, more specifically $\mathrm{C}-\mathrm{H}$ bending, and the peaks at 1574 and $1700 \mathrm{~cm}^{-1}$ are associated with carboxyl groups. Besides, the Molinia caerulea and Elaeis guineensis biochar shows a $\mathrm{C}-\mathrm{O}$ group $\left(1111 \mathrm{~cm}^{-1}\right)$ that corresponds to a secondary alcohol, while the Picea biochar shows the C-O group $\left(1196 \mathrm{~cm}^{-1}\right)$ associated with a tertiary alcohol. These groups are mostly found in biochar that are obtained from sources that tend to be polar, hydrophilic, and relatively reactive, such as lignocellulosic feedstocks. Furthermore, the oxygen-containing functional groups have variable charge, at a higher $\mathrm{pH}$, the carboxylic acids give up protons and become negatively charged $\left(-\mathrm{COO}^{-}\right)[71,75,76]$.

The spectra of Molinia cerulea and Elaeis guineensis show peaks at 2000 and $2100 \mathrm{~cm}^{-1}$, corresponding to triple bond of alkynes that are part of the lignocellulose [77-79]. Finally, only the biochar of Elaeis guineensis show the presence of asymmetric $\left(2910 \mathrm{~cm}^{-1}\right)$ and symmetric $\left(2850 \mathrm{~cm}^{-1}\right) \mathrm{C}-\mathrm{H}$ stretching bands associated with aliphatic functional groups, which decrease in intensity due to structural changes occurred during pyrolysis that produce a decrease in aliphatic compounds [80,81]. The spectra obtained from the biochar of Picea, Molinia caerule and Elaeis guineensis, don't show high intensities due to the carbonization processes to which the biomass is subjected. In addition, the functional groups are related to lignocellulosic feedstocks such as those used in this work. Finally, it is suggested that the differences found in the spectra may be due to the conditions of the thermal conversion process of biochar, since many authors $[21,82]$ report that variables 
such as reactor type, heating rate, temperature, residence time, oxygen concentration, etc. are significant variables that can affect the characteristics of biochar produced.

\subsection{Carbon Dots Characterization}

\subsubsection{Chemical Characterization}

The FTIR spectra of the three biochar-derived C-Dots are depicted in Figure 2. These spectra, unlike those obtained for biochar, show an increase in the intensity of the bands and a change in their position, which suggests an increase in the amount (per unit volume) of some functional groups, and a change in the state of hybridization or electronic distribution of molecular bonds. Furthermore, the absence of the bands between 1700 and $2100 \mathrm{~cm}^{-1}$ suggests the formation of other functional groups due to the hydrothermal process with $\mathrm{KMnO}_{4}$.

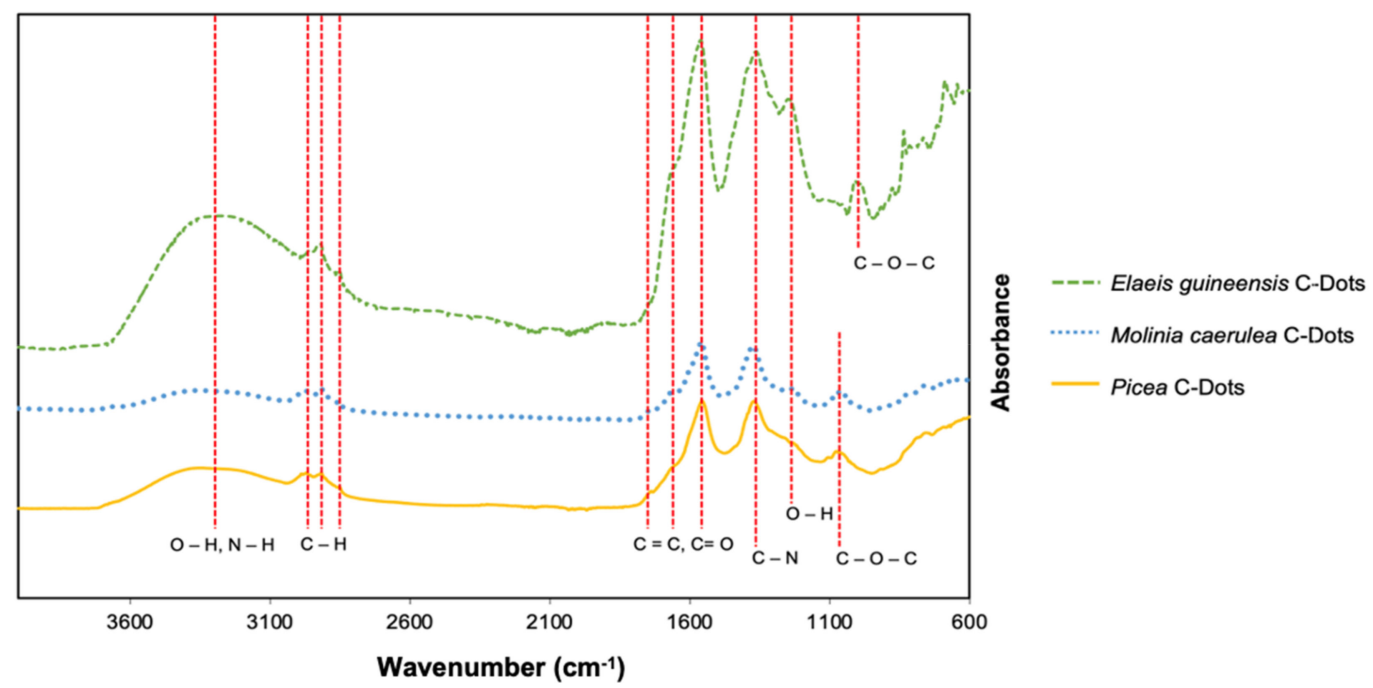

Figure 2. Picea, Molinia caerulea, and Elaeis guineensis C-Dots FTIR spectra.

The bands between 700 and $900 \mathrm{~cm}^{-1}$ shown in the spectra are associated with con $\mathrm{C}-\mathrm{H}$ bending, as are the spectra of biochar. The existence of $\mathrm{C}-\mathrm{O}-\mathrm{C}$ bonds leads to the absorption peak at $990 \mathrm{~cm}^{-1}$ for Elaeis guineensis C-Dots and $1045 \mathrm{~cm}^{-1}$ for Picea and Molinia caerulea C-Dots [83,84], and the peak at $1236 \mathrm{~cm}^{-1}$ is associated with C-O stretching $[85,86]$. One of the most intense peaks of all the spectra occurs at $1370 \mathrm{~cm}^{-1}$ which corresponds to C-N [87-89]; the bands located around 1550-1750 $\mathrm{cm}^{-1}$ are assigned, for some authors to $\mathrm{C}=\mathrm{N}[89,90]$, while other authors associated these bands with the stretching vibration of $\mathrm{C}=\mathrm{C}$ and carbonyl bonds $(\mathrm{C}=\mathrm{O})[83-85,91]$. Moreover, the band around $1700 \mathrm{~cm}^{-1}$ could indicate the vibration of the carbonyl bond of a carboxylic acid, however, because it's weak, it could represent the deprotonation of the group and the apparition of the carboxylate group $\left(\mathrm{COO}^{-}\right)$[20]. The presence of carbonyl groups could allow, in future works, the functionalization of these carbonaceous materials with molecules that have amine groups available through the carbodiimide technique.

Finally, the peaks displayed between $2850 \mathrm{~cm}^{-1}$ and $2950 \mathrm{~cm}^{-1}$ are from C-H stretching vibration [91-93], and the broad absorption band within 3100-3600 $\mathrm{cm}^{-1}$ derives from the stretching vibration of hydroxyl bonds $(\mathrm{O}-\mathrm{H})$ and $\mathrm{N}-\mathrm{H}[83,84]$. This data suggest that the C-Dots obtained from Picea, Molinia caerulea and Elaeis guineensis present large hydrophilic groups indicating the formation of water-soluble materials, and the presence of carbonyl moieties suggest that the C-Dots could be slightly negatively charged.

\subsubsection{Morphology and Stability}

The HR-TEM and the DLS were utilized to investigate the morphology and average size of the biochar-derived C-Dots. The size distribution obtained by measuring the hydrodynamic diameter of C-Dots (1000 ppm) derived from Picea, Molinia caerulea and 
Elaeis guineensis; by DLS indicates that these nanoparticles have a total hydrodynamic diameter of $113 \pm 13.4,122.7 \pm 2$, and $105.4 \pm 7.1 \mathrm{~nm}$ and the polydispersity index are $0.19 \pm 0.01,0.18 \pm 0.04$, and $0.2 \pm 0.03$, respectively. Besides, the DLS graphs show that the three types of C-Dots are bimodal and have a second population of particles with hydrodynamic diameter less than $5 \mathrm{~nm}$. However, HR-TEM images (Figure 3) reveal that the three types of the extracted biochar nanoparticles (Picea, Molinia caerulea and Elaeis guineensis) are mono-dispersed, and they have a nearly spherical shape with an average size of $4.2 \pm 1.2,6.2 \pm 1.9$ and $2.5 \pm 0.7 \mathrm{~nm}$, respectively (Figure 3) (the size distribution was determined with 100 particles, which are founded in various TEM images related to different zones in the sample). Besides, the HR-TEM images show some aggregation between the particles, which explains the total hydrodynamic diameter measured with DLS. It is comparable to other reported works [94-96]. C-Dots derived from Elaeis guineensis biochar are smaller than the other particles and the C-Dots derived from Molinia caerulea biochar have the greatest variability in size. However, since all the particles are in the range less than $10 \mathrm{~nm}$, they are considered C-Dots.
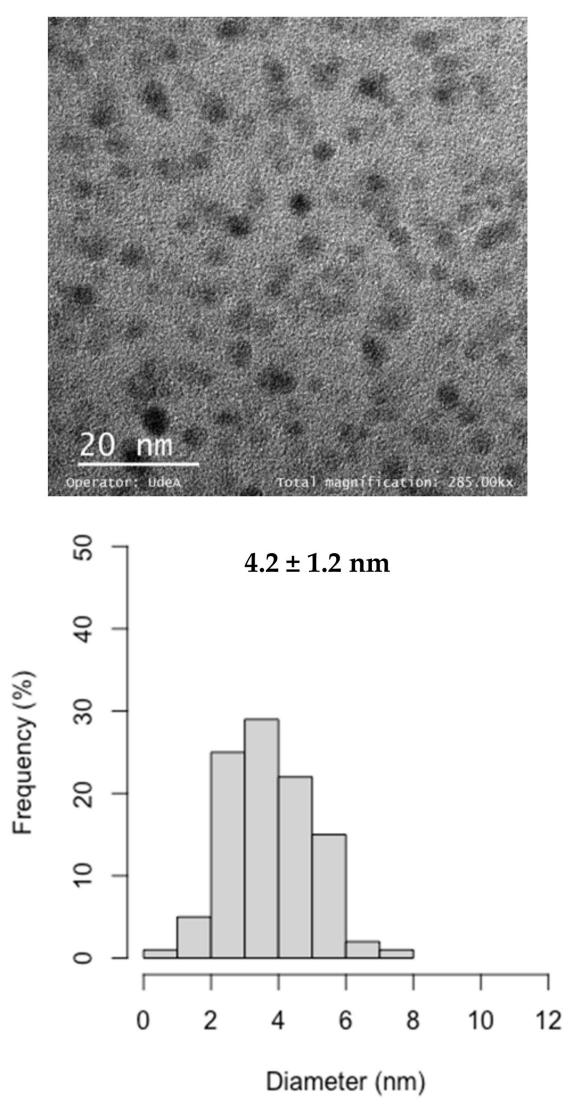

(a)
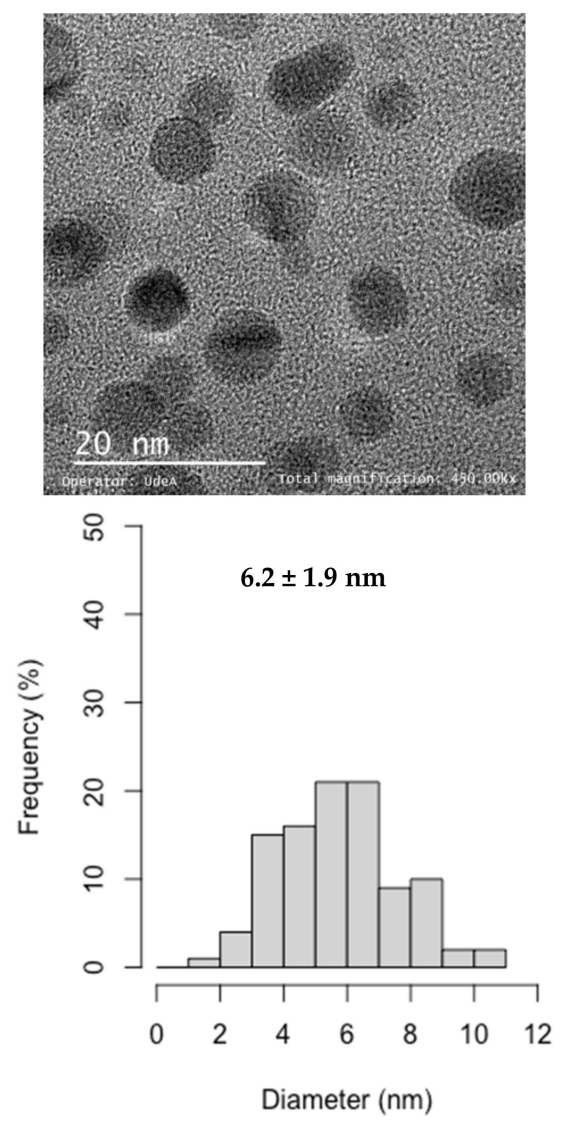

(b)
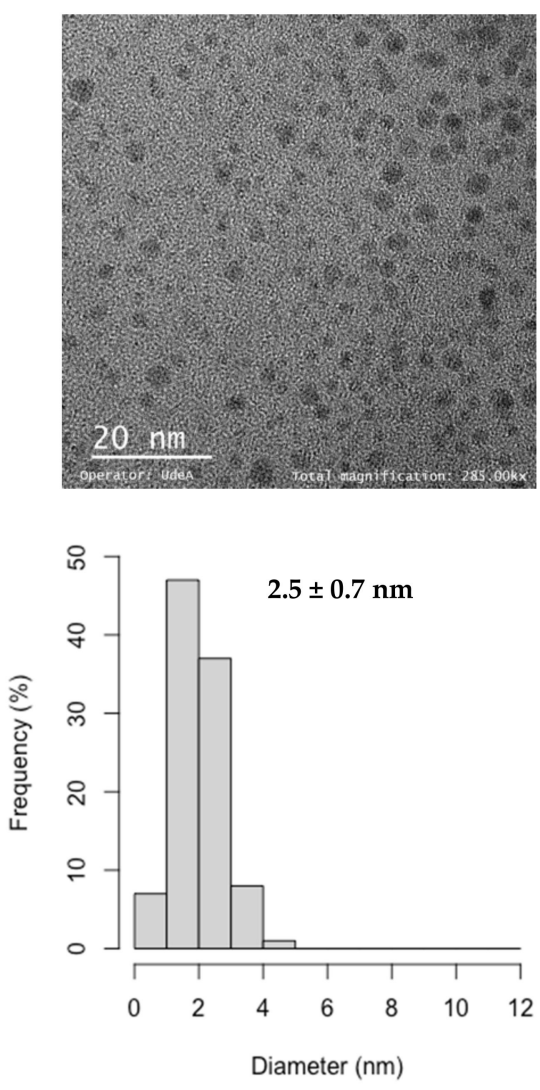

(c)

Figure 3. TEM images of (a) Picea, (b) Molinia caerulea and (c) Elaeis guineensis. Histogram of particle diameter distribution of C-Dots (inset).

The $\mathrm{Z}$ potential is an indicator of nanoparticles stability since it is a measure of the charge repulsion or attraction between the particles from its surface to the boundary of the diffuse layer. The measurements affording a value of $-58.85 \pm 7.7,-48.7 \pm 1.2$, and $-56.2 \pm 6.2$ for C-Dots synthetized from Picea, Molinia caerulea and Elaeis guineensis, respectively. These values indicate that the nanoparticles have great stability. 


\subsubsection{Optical Properties}

The fluorescence spectra (Figure 4$)$ show the maximum emission wavelength $\left(\lambda_{\mathrm{em}}\right)$ at similar value: 430, 420, and $420 \mathrm{~nm}$ for Picea, Molinia caerulea and Elaeis guineensis, respectively. The maximum excitation wavelength is also similar, ranging from $300 \mathrm{~nm}$ to $320 \mathrm{~nm}$. The optimal excitation and emission wavelength combination are shown as an insert of Figure 4. All the obtained C-Dots show a brownish yellow color under daylight, and blue emission under UV light.

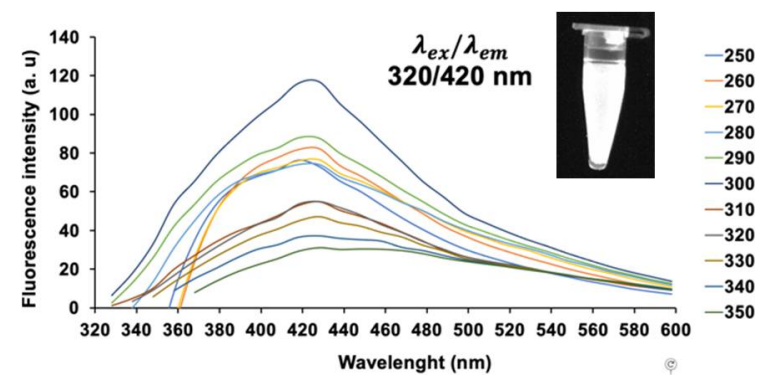

(a)

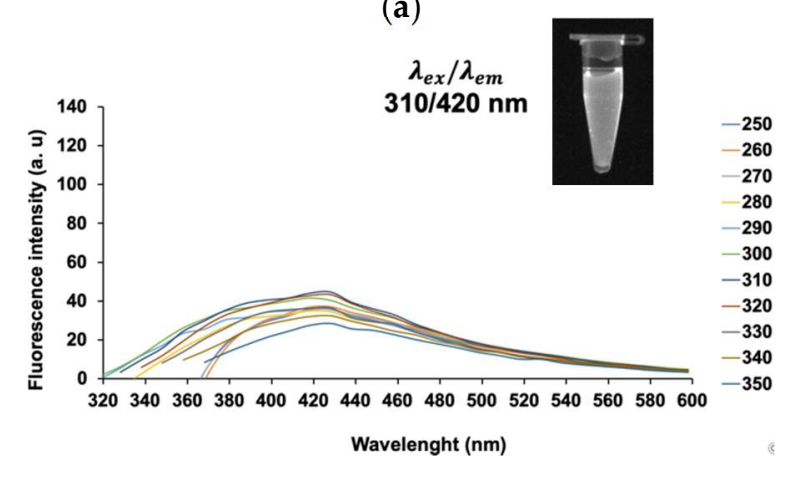

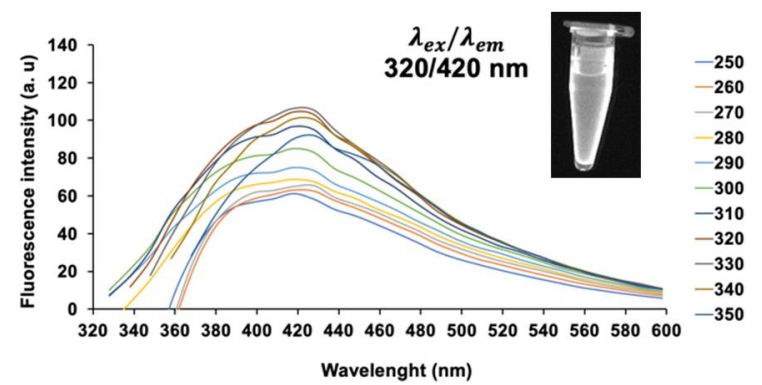

(b)

(c)

Figure 4. Emission spectra of C-Dots under different excitation wavelengths. (a) Picea. (b) Molinia caerulea. (c) Elaeis guineensis.

Usually, C-Dots exhibit an excitation-dependent photoluminescence that are related to state defects [17]. This behavior is particular for Elaeis guineensis whose intensity decrease between $360 \mathrm{~nm}$ and $400 \mathrm{~nm}$. In this range is also a red shift photoluminescence that could be explained by the surface oxidation degree as a theory for the fluorescence origin [23]. Some authors found these defects can trap excitons, and the radiation from the recombination of trapped excitons causes the red-shift emission [97-99]. The band gap between the lowest unoccupied molecular orbital and the highest occupied molecular orbital reduces with the increase of oxygen content on the C-dots surface, that is, red-shifted emission is derived from increasing surface oxidation degree [23,100]. For Picea and Molinia caerulea, there is no visible red shift phenomenon, and the emission peak is preserved for the different excitation wavelengths, just changing its intensity. This behavior could be explained by the surface functional groups as an alternative theory for the fluorescence origin [23]. According to that, surface states are correlated to surface functional groups, such as $\mathrm{C}=\mathrm{O}$ and $\mathrm{C}=\mathrm{N}$. Those groups are present in all the $\mathrm{C}$-dots (Figure 2) and were proved to be closely related to the fluorescence $[101,102]$. The functional groups can introduce new energy levels and further produce new electron transitions [23].

The UV-Vis spectra (Figure 5) were investigated at a concentration of $500 \mathrm{ppm}$. Picea and Molinia caerulea show the same behavior, a characteristic slight absorption signal at $244 \mathrm{~nm}$, while Elaeis guineensis shows a slight absorption signal at $244 \mathrm{~nm}$ and a more visible signal at $280 \mathrm{~nm}$. Absorption signals between $240 \mathrm{~nm}$ and $290 \mathrm{~nm}$ are attributed to the $\pi-\pi^{*}$ or $\mathrm{n}-\pi^{*}$ transitions and suggest the presence of $\mathrm{C}=\mathrm{O}, \mathrm{C}=\mathrm{C}$, and $\mathrm{C}=\mathrm{N}$ surface functional groups [103]. On the other hand, the signal at $244 \mathrm{~nm}$ could be attributed precisely to $\mathrm{n}-\pi^{*}$ 
transitions and could explain the slightly blue shift in the fluorescence spectra of Picea and Molinia caerulea when they are exciting with longer wavelengths [16,104].

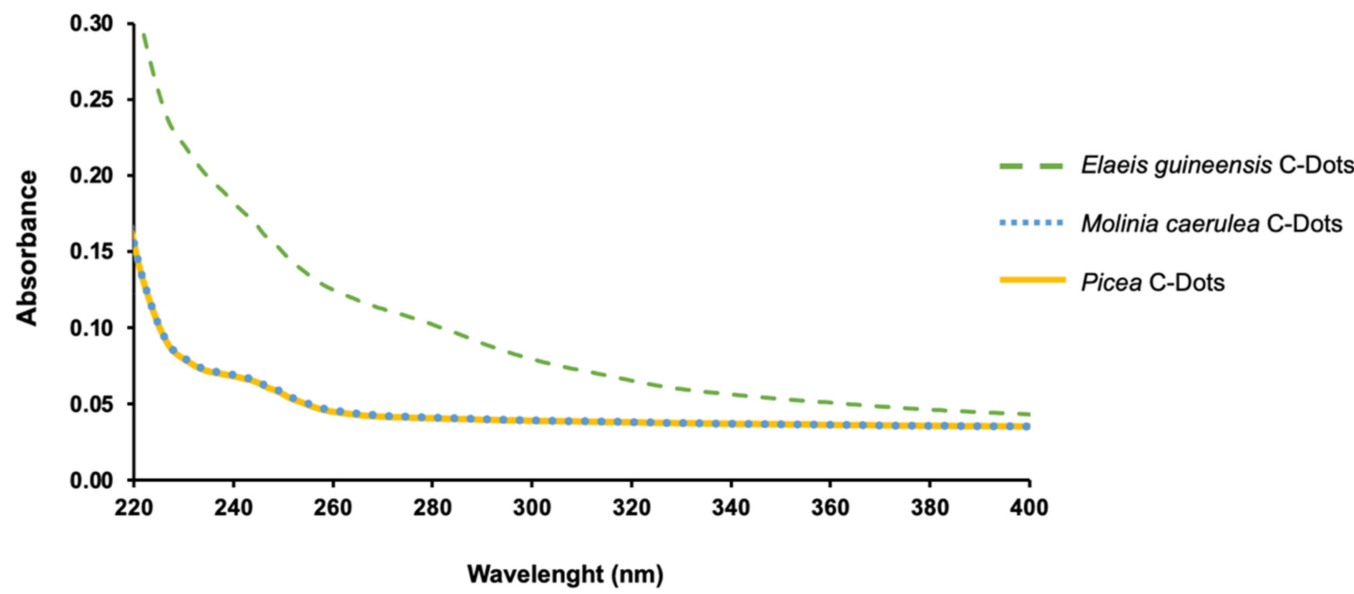

Figure 5. UV-Vis spectra of Picea, Molinia caerulea, and Elaeis guineensis C-Dots.

The Quantum Yields (QY) of the Picea, Molinia caerulea and Elaeis guineensis C-Dots were $5.44,8.39,2.31 \%$ respectively, using quinine sulfate ( $Q Y$ of 0.54 in $0.5 \mathrm{M} \mathrm{H}_{2} \mathrm{SO}_{4}$ [105]) as the reference. Table 2 shows the comparison of several biomass-derived C-Dots QYs and excitation wavelengths with the results obtained in this work. Moreover, for C-Dots derived from biomass using the hydrothermal method, the QYs can range from $2.3 \%$ to $21.7 \%$ depending mostly on its size, carbon precursor, and processing parameters [106-108]. It is suggested that the high quantum yield obtained for the C-Dots synthesized from Molinia caerulea, is because the biochar from this source is one with the highest nitrogen and sulfur content (Table 1), compared to Picea and Elaeis guineensis, which influence the production of C-Dots with heteroatoms and are related to the increase in fluorescence intensity and its quantum yield [109-111]. For instance, Zhu et al. [99], obtained C-Dots doped with nitrogen and synthesized from citric acid and ethylenediamine with a QY of $80 \%$. Likewise, several authors have shown an increase in the QY of C-Dots through doping with nitrogen or sulfur heteroatoms [112-117].

Table 2. Comparison of several hydrothermally produced C-Dots with different biomass precursors.

\begin{tabular}{cccc}
\hline Carbon Precursor & $\lambda_{\text {exc }}(\mathbf{n m})$ & QY\% & Reference \\
\hline Willow Bark & 360 & 6 & {$[118]$} \\
\hline Pomelo peel & 360 & 6.9 & {$[119]$} \\
\hline Citrus pectin & 360 & 1.1 & {$[120]$} \\
\hline Sugarcane juice & 390 & 5.67 & {$[95]$} \\
\hline Winter melon & 360 & 7.51 & {$[121]$} \\
\hline Coffee beans & 365 & 3.80 & {$[122]$} \\
\hline Picea & 310 & 5.44 & This work \\
\hline Molinia caerulea & 320 & 8.39 & This work \\
\hline Elaeis guineensis & 310 & 2.31 & This work \\
\hline
\end{tabular}

\subsubsection{Ecotoxicity}

In the present work, the aquatic toxicity analysis was carried out because environmental applications of C-Dots are projected (detection of heavy metals, pesticides, and endocrine disruptors) but also to determine the toxic potential that this nanomaterial may have at the end of its life cycle, by encountering water sources and aquatic biota. The Microtox $^{\mathrm{TM}}$ test results for the different C-Dots samples are shown in Figure 6. The gamma 
value equal to unity represents the EC50 in percentage value, which can be seen to be met and exceeded for very low values of Picea (2.35\% with slightly erratic values) and higher values of Molinia caerulea (41.92\%). In the case of Elaeis guineensis C-Dots, the unit value is not reached, and the projected slope implies that extremely high values would be necessary to cause any toxic effect (858.6\%).

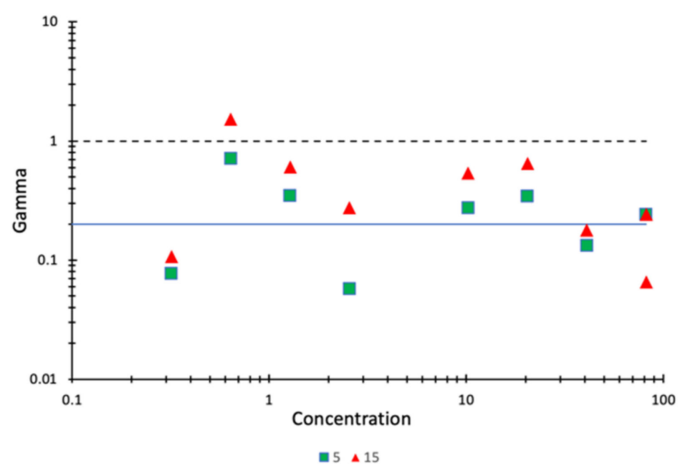

(a)

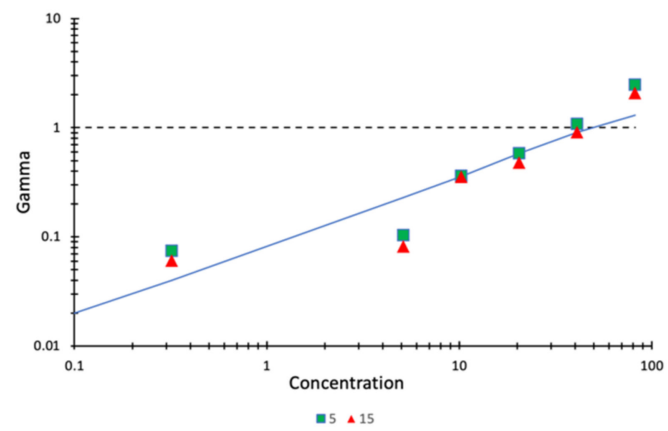

(b)

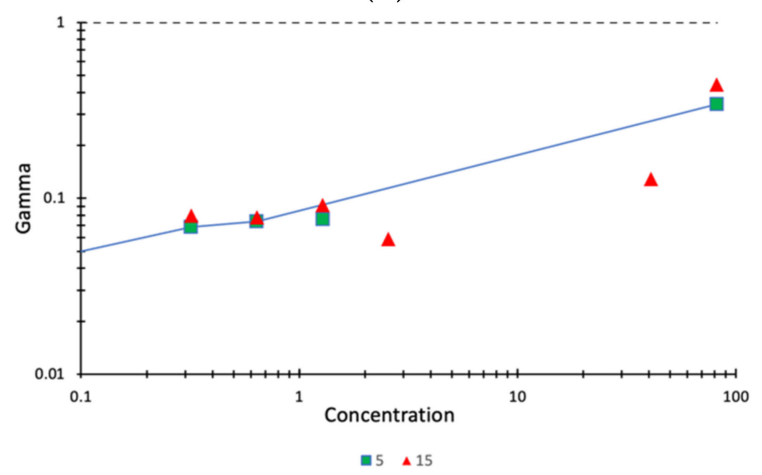

(c)

Figure 6. Aquatic toxicity test results for Picea (a), Molinia caerulea (b) and Elaeis guineensis (c). Gamma $=1$ corresponds to the EC50. Horizontal axis corresponds to the percentage of the concentration, where $100 \%$ equals 1000 ppm.

The different samples present EC50 values in concentration units, taken at 15 min of the test of $23.5 \mathrm{mg} / \mathrm{L}, 419.2 \mathrm{mg} / \mathrm{L}$ and $8586 \mathrm{mg} / \mathrm{L}$ for Picea, Molinia caerulea and Elaeis guineensis C-Dots respectively. According to these results, we can classify them as highly toxic (Picea C-Dots), moderately toxic (Molinia caerulea C-Dots) and non-toxic (Elaeis guineensis C-Dots) [123].

The toxicity of nanomaterials, in general, is a growing field of study, which includes initiatives like US NanoEPA [124] and EU NanoSafety cluster [125]. Toxicity depends on starting material, dose, size, surface chemistry, and durability; additionally, various routes of exposure are considered with different effects on organisms [126]. Picea C-Dots present a 
marked toxicity, which can be explained by the characteristic mentioned previously and their smaller size (Figure 3). Most studies focused on the safety of nanomaterials agree that size is the main factor of toxicity of nanomaterials with respect to the material on a macroscopic scale, mainly due to their effects through biological barriers, in the surface area and the density of absorption; this triggers endocytosis/exocytosis, oxidative stress, reactive oxygen species (ROS), cell damage and apoptosis [127].

C-Dots have a lower toxicity than quantum dots, traditionally synthesized from heavy metals [127]. However, ecotoxicological evaluations of C-Dots are scarce, despite being a priority test in terms of safety. Few studies have been carried out in bioindicator organisms such as microcrustaceans (Daphnia magna) and zebra fish (Danio rerio), showing that concentrations up to $200 \mathrm{mg} / \mathrm{L}$ can be cleared without acute toxic effects [128]. However, in the present work, it was found that Picea C-Dots are toxic for Vibrio fischeri at lower values. This shows that the Microtox ${ }^{\mathrm{TM}}$ assays are more sensitive [123] and that more data is needed at the ecotoxicological level to follow the in vivo testing process. The damage routes of C-Dots in these organisms are related to oxidative stress [128]. However, several authors agree that carbonaceous nanomaterials have little or no bioaccumulation capacity, so there would be no chronic toxicity [127]. Future work is required to further clarify these findings.

\section{Conclusions}

This work shows that Picea C-Dots have excellent optical properties. However, they exhibit high ecotoxicity, which limits their applications. Molinia caerulea and Elaeis guineensis C-Dots have low or no toxicity, but Elaeis guineensis C-Dots has the lowest fluorescence intensity with respect to the others. All the C-Dots have high values of negative $\mathrm{Z}$ potential, which indicate colloidal stability. Besides, they have excellent chemical groups on the surface that would allow for easy functionalization to other molecules, so they have the potential, especially Molinia caerulea and Elaeis guineensis C-Dots, for use in the development of optical biosensors with applications in the detection of environmental contaminants and pathogens. However, the optical properties (quantum yield) could be optimized to improve their performance. These results allow for the encouragement of the valorization of agro-industrial waste for its transformation into biochar and its use beyond soil amendment. Finally, future works could include more studies focused on the optimization of the optical properties of C-Dots, as well as the study of their ecotoxicology that allows a safe application of these nanomaterials in different fields of knowledge.

Supplementary Materials: The following are available online at https: / www.mdpi.com/article/ 10.3390/pr9071095/s1, Table S1: Physicochemical analysis of Molinia caerulea biochar, Table S2: Physicochemical analysis of Elaeis guineensis biochar.

Author Contributions: Devised and directed the project, M.J., M.E.L., S.B. and J.P.; designed the experiments and conceptualized the paper, K.B., M.I.G. and J.P.A.; synthetized the C-Dots, J.P., M.E.L., K.B., M.I.G. and J.P.A.; analyzed the biochar characterization data, M.I.G.; conducted the optical properties experiment and analysis, K.B. and M.I.G.; conducted the morphology and stability experiments and analysis, K.B.; analyzed the High-Resolution Transmission Electronical Microscopy data, M.E.L. and K.B.; conducted the Attenuated Total Reflection-Fourier Transform Infrared experiments and analysis, J.P.A. and K.B.; analyzed the Microtox ${ }^{\mathrm{TM}}$ data, M.I.G.; performed the Quantum Yield calculations, J.P.A.; wrote the manuscript in consultation, K.B., M.I.G., J.P.A., M.J., M.E.L., J.P. and S.B. All authors discussed the results and commented on the manuscript. All authors have read and agreed to the published version of the manuscript.

Funding: This work was funded by the Ministry of Science, Technology, and Innovation of the Colombian government (code 133380764415, contract number CT- 800-2018) (code 111571451059, contract number FP44842-147-2016).

Institutional Review Board Statement: Not applicable.

Informed Consent Statement: Not applicable. 
Data Availability Statement: All data generated or analyzed during this study are included in this published article and its supplementary information file.

Acknowledgments: The authors would like to thank the Ministry of Science, Technology, and Innovation of the Colombian government for financing the projects "Desarrollo de un inmunosensor basado en Carbon Dots para la detección de tuberculosis" (code 133380764415, contract number CT- 800-2018) and "Redes de biosensores aplicados a la detección de contaminantes tóxicos en fuentes naturales que abastecen a las plantas de potabilización" (code 111571451059, contract number FP44842-147-2016). The authors thank the Ministry of Science, Technology, and Innovation of the Colombian government for the scholarship for doctoral studies of Maria Isabel Gaviria (Grant number 785 of 2017). Jersson Placido and Sandra Bustamante would like to thank the European Regional Development Fund/Welsh Government funded BEACON+ research program (Swansea University).

Conflicts of Interest: The authors declare no conflict of interest.

\section{References}

1. United Nations. The Sustainable Development Goals Report; United Nations: New York, NY, USA, 2020; ISSN 2521-6899.

2. Benedetti, V.; Patuzzi, F.; Baratieri, M. Characterization of char from biomass gasification and its similarities with activated carbon in adsorption applications. Appl. Energy 2018, 227, 92-99. [CrossRef]

3. Yao, Z.; You, S.; Ge, T.; Wang, C.-H. Biomass gasification for syngas and biochar co-production: Energy application and economic evaluation. Appl. Energy 2018, 209, 43-55. [CrossRef]

4. Vamvuka, D.; Sfakiotakis, S.; Pantelaki, O. Evaluation of gaseous and solid products from the pyrolysis of waste biomass blends for energetic and environmental applications. Fuel 2019, 236, 574-582. [CrossRef]

5. Kong, X.; Zhu, Y.; Lei, H.; Wang, C.; Zhao, Y.; Huo, E.; Lin, X.; Zhang, Q.; Qian, M.; Mateo, W.; et al. Synthesis of graphene-like carbon from biomass pyrolysis and its applications. Chem. Eng. J. 2020, 399, 125808. [CrossRef]

6. Li, J.; Dai, J.; Liu, G.; Zhang, H.; Gao, Z.; Fu, J.; He, Y.; Huang, Y. Biochar from microwave pyrolysis of biomass: A review. Biomass Bioenergy 2016, 94, 228-244. [CrossRef]

7. Chen, T.; Liu, R.; Scott, N.R. Characterization of energy carriers obtained from the pyrolysis of white ash, switchgrass and corn stover-Biochar, syngas and bio-oil. Fuel Process. Technol. 2016, 142, 124-134. [CrossRef]

8. Muegue, L.C.D.; González, J.C.A.; Mesa, G.P. Characterization and Potential Use of Biochar for the Remediation of Coal Mine Waste Containing Efflorescent Salts. Sustainability 2017, 9, 2100. [CrossRef]

9. Giri, B.S.; Goswami, M.; Singh, R. Review on Application of Agro-Waste Biomass Biochar for Adsorption and Bioremediation Dye. Biomed. J. Sci. Tech. Res. 2017, 1, 1928-1930.

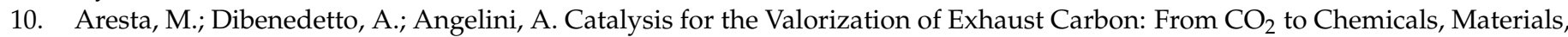
and Fuels. Technological Use of $\mathrm{CO}_{2}$. Chem. Rev. 2014, 114, 1709-1742. [CrossRef]

11. Shalini, S.S.; Palanivelu, K.; Ramachandran, A.; Raghavan, V. Biochar from biomass waste as a renewable carbon material for climate change mitigation in reducing greenhouse gas emissions-A review. Biomass Convers. Biorefin. 2020, 1-21. [CrossRef]

12. Tan, X.; Liu, S.-B.; Liu, Y.-G.; Gu, Y.-L.; Zeng, G.-M.; Hu, X.-J.; Wang, X.; Jiang, L.-H. Biochar as potential sustainable precursors for activated carbon production: Multiple applications in environmental protection and energy storage. Bioresour. Technol. 2017, 227, 359-372. [CrossRef]

13. Plácido, J.; Bustamante-López, S.; Meissner, K.; Kelly, D.; Kelly, S. NanoRefinery of carbonaceous nanomaterials: Complementing dairy manure gasification and their applications in cellular imaging and heavy metal sensing. Sci. Total Environ. 2019, 689, 10-20. [CrossRef]

14. Plácido, J.; López, S.B.; Meissner, K.; Kelly, D.; Kelly, S. Multivariate analysis of biochar-derived carbonaceous nanomaterials for detection of heavy metal ions in aqueous systems. Sci. Total Environ. 2019, 688, 751-761. [CrossRef]

15. Pourreza, N.; Ghomi, M. Green synthesized carbon quantum dots from Prosopis juliflora leaves as a dual off-on fluorescence probe for sensing mercury (II) and chemet drug. Mater. Sci. Eng. C 2019, 98, 887-896. [CrossRef]

16. Atchudan, R.; Edison, T.N.J.I.; Perumal, S.; Selvam, N.C.S.; Lee, Y.R. Green synthesized multiple fluorescent nitrogen-doped carbon quantum dots as an efficient label-free optical nanoprobe for in vivo live-cell imaging. J. Photochem. Photobiol. A Chem. 2019, 372, 99-107. [CrossRef]

17. Vasimalai, N.; Vilas-Boas, V.; Gallo, J.; Cerqueira, M.D.F.; Menéndez-Miranda, M.; Costa-Fernández, J.M.; Diéguez, L.; Espiña, B.; Fernández-Argüelles, M.T. Green synthesis of fluorescent carbon dots from spices for in vitro imaging and tumour cell growth inhibition. Beilstein J. Nanotechnol. 2018, 9, 530-544. [CrossRef]

18. Kang, C.; Huang, Y.; Yang, H.; Yan, X.F.; Chen, Z.P. A Review of Carbon Dots Produced from Biomass Wastes. Nanomaterials 2020, 10, 2316. [CrossRef] [PubMed]

19. Campuzano, S.; Yáñez-Sedeño, P.; Pingarrón, J.M. Carbon Dots and Graphene Quantum Dots in Electrochemical Biosensing. Nanomaterials 2019, 9, 634. [CrossRef] [PubMed]

20. Plácido, J.; Bustamante-López, S.; Meissner, K.; Kelly, D.; Kelly, S. Comparative study of the characteristics and fluorescent properties of three different biochar derived-carbonaceous nanomaterials for bioimaging and heavy metal ions sensing. Fuel Process. Technol. 2019, 196, 106163. [CrossRef] 
21. Plácido, J.; Bustamante-López, S.; Meissner, K.; Kelly, D.; Kelly, S. Microalgae biochar-derived carbon dots and their application in heavy metal sensing in aqueous systems. Sci. Total Environ. 2019, 656, 531-539. [CrossRef]

22. Abdul, S.; Nor, R.; Zobir, M. Synthesis, Technology and Applications of Carbon Nanomaterials; Elsevier: Oxford, UK, 2019.

23. Liu, M.L.; Bin Chen, B.; Li, C.M.; Huang, C.Z. Carbon dots: Synthesis, formation mechanism, fluorescence origin and sensing applications. Green Chem. 2019, 21, 449-471. [CrossRef]

24. Wang, R.; Lu, K.-Q.; Tang, Z.-R.; Xu, Y.-J. Recent progress in carbon quantum dots: Synthesis, properties and applications in photocatalysis. J. Mater. Chem. A 2017, 5, 3717-3734. [CrossRef]

25. Liu, W.; Li, C.; Ren, Y.; Sun, X.; Pan, W.; Li, Y.; Wang, J.; Wang, W. Carbon dots: Surface engineering and applications. J. Mater. Chem. B 2016, 4, 5772-5788. [CrossRef]

26. Zheng, M.; Liu, S.; Li, J.; Qu, D.; Zhao, H.; Guan, X.; Hu, X.; Xie, Z.; Jing, X.; Sun, Z. Integrating Oxaliplatin with Highly Luminescent Carbon Dots: An Unprecedented Theranostic Agent for Personalized Medicine. Adv. Mater. 2014, 26, 3554-3560. [CrossRef]

27. Yuan, Y.; Guo, B.; Hao, L.; Liu, N.; Lin, Y.; Guo, W.; Li, X. Doxorubicin-loaded environmentally friendly carbon dots as a novel drug delivery system for nucleus targeted cancer therapy. Colloids Surfaces B Biointerfaces 2017, 159, 349-359. [CrossRef]

28. D'Souza, S.L.; Deshmukh, B.; Bhamore, J.R.; Rawat, K.A.; Lenka, N.; Kailasa, S.K. Synthesis of fluorescent nitrogen-doped carbon dots from dried shrimps for cell imaging and boldine drug delivery system. RSC Adv. 2016, 6, 12169-12179. [CrossRef]

29. Mehta, V.N.; Chettiar, S.S.; Bhamore, J.R.; Kailasa, S.K.; Patel, R.M. Green Synthetic Approach for Synthesis of Fluorescent Carbon Dots for Lisinopril Drug Delivery System and their Confirmations in the Cells. J. Fluoresc. 2017, 27, 111-124. [CrossRef] [PubMed]

30. Wang, C.; Pan, C.; Wei, X.; Yang, F.; Wu, W.; Mao, L. Emissive carbon dots derived from natural liquid fuels and its biological sensing for copper ions. Talanta 2020, 208, 120375. [CrossRef] [PubMed]

31. Radhakrishnan, K.; Sivanesan, S.; Panneerselvam, P. Turn-On fluorescence sensor based detection of heavy metal ion using carbon dots@graphitic-carbon nitride nanocomposite probe. J. Photochem. Photobiol. A Chem. 2020, 389, 112204. [CrossRef]

32. Brachi, P. Synthesis of fluorescent carbon quantum dots (CQDs) through the mild thermal treatment of agro-industrial residues assisted by $\gamma$-alumina. Biomass Convers. Biorefinery 2020, 10, 1301-1312. [CrossRef]

33. Luo, X.; Han, Y.; Chen, X.; Tang, W.; Yue, T.; Li, Z. Carbon dots derived fluorescent nanosensors as versatile tools for food quality and safety assessment: A review. Trends Food Sci. Technol. 2020, 95, 149-161. [CrossRef]

34. Bui, T.T.; Park, S.-Y. A carbon dot-hemoglobin complex-based biosensor for cholesterol detection. Green Chem. 2016, 18, 4245-4253. [CrossRef]

35. Pirsaheb, M.; Mohammadi, S.; Salimi, A. Current advances of carbon dots based biosensors for tumor marker detection, cancer cells analysis and bioimaging. TrAC Trends Anal. Chem. 2019, 115, 83-99. [CrossRef]

36. Chen, Z.-H.; Han, X.-Y.; Deng, L.-X.; Lin, Z.-Y.; Mu, F.-Y.; Zhang, S.; Shi, G.; Zhang, M. A self-calibrating logic system and oxidase-based biosensor using $\mathrm{Tb}^{3+}$-doped carbon dots/DNA conjugates. Talanta 2019, 191, 235-240. [CrossRef] [PubMed]

37. Bhattacharyya, D.; Sarswat, P.K.; Free, M.L. Quantum dots and carbon dots based fluorescent sensors for TB biomarkers detection. Vacuum 2017, 146, 606-613. [CrossRef]

38. He, L.; Yang, Y.; Kim, J.; Yao, L.; Dong, X.; Li, T.; Piao, Y. Multi-layered enzyme coating on highly conductive magnetic biochar nanoparticles for bisphenol A sensing in water. Chem. Eng. J. 2020, 384, 123276. [CrossRef]

39. Liu, M.L.; Bin Chen, B.; He, J.H.; Li, C.M.; Li, Y.F.; Huang, C.Z. Anthrax biomarker: An ultrasensitive fluorescent ratiometry of dipicolinic acid by using terbium(III)-modified carbon dots. Talanta 2019, 191, 443-448. [CrossRef]

40. Spanu, D.; Binda, G.; Dossi, C.; Monticelli, D. Biochar as an alternative sustainable platform for sensing applications: A review. Microchem. J. 2020, 159, 105506. [CrossRef]

41. Liu, H.; Ding, J.; Zhang, K.; Ding, L. Construction of biomass carbon dots based fluorescence sensors and their applications in chemical and biological analysis. TrAC Trends Anal. Chem. 2019, 118, 315-337. [CrossRef]

42. Brachi, P. Synthesis of carbon dots (CDs) through the fluidized bed thermal treatment of residual biomass assisted by $\gamma$-alumina. Appl. Catal. B Environ. 2020, 263, 118361. [CrossRef]

43. Pooja, D.; Singh, L.; Thakur, A.; Kumar, P. Green synthesis of glowing carbon dots from Carica papaya waste pulp and their application as a label-freechemo probe for chromium detection in water. Sens. Actuators B Chem. 2019, 283, 363-372. [CrossRef]

44. Hardman, R. A Toxicologic Review of Quantum Dots: Toxicity Depends on Physicochemical and Environmental Factors. Environ. Health Perspect. 2006, 114, 165-172. [CrossRef]

45. Oberdörster, G.; Oberdörster, E.; Oberdörster, J. Nanotoxicology: An Emerging Discipline Evolving from Studies of Ultrafine Particles. Environ. Health Perspect. 2005, 113, 823-839. [CrossRef] [PubMed]

46. Chunying, C.; Haifang, W. Biomedical Applications and Toxicology of Carbon Nanomaterials; John Wiley \& Sons: Hoboken, NJ, USA, 2016.

47. Wang, F.; Chen, P.; Feng, Y.; Xie, Z.; Liu, Y.; Su, Y.; Zhang, Q.; Wang, Y.; Yao, K.; Lv, W.; et al. Facile synthesis of N-doped carbon dots/g- $\mathrm{C}_{3} \mathrm{~N}_{4}$ photocatalyst with enhanced visible-light photocatalytic activity for the degradation of indomethacin. Appl. Catal. B Environ. 2017, 207, 103-113. [CrossRef]

48. Farre, M.; Gajda-Schrantz, K.; Kantiani, L.; Barceló, D. Ecotoxicity and analysis of nanomaterials in the aquatic environment. Anal. Bioanal. Chem. 2008, 393, 81-95. [CrossRef]

49. Jahan, S.; Bin Yusoff, I.; Alias, Y.B.; Bin Abu Bakar, A.F. Reviews of the toxicity behavior of five potential engineered nanomaterials (ENMs) into the aquatic ecosystem. Toxicol. Rep. 2017, 4, 211-220. [CrossRef] [PubMed]

50. Rana, S.; Kalaichelvan, P.T. Ecotoxicity of Nanoparticles. ISRN Toxicol. 2013, 2013, 574648. [CrossRef] 
51. Díaz, L.C.; Pino, N.; Peñuela, G. Biochar from oil palm waste as an amendment for the remediation of soil disturbed by open-cast coal mining. Glob. Adv. Res. J. Eng. Technol. Innov. 2016, 5, 17-22.

52. Erzinger, G.S.; Schmoeller, F.; Pinto, L.H.; Américo, L.; Hemmersbach, R.; Hauslage, J.; Häder, D.-P. Bioluminescence systems in environmental biosensors. In Bioassays; Elsevier: Amsterdam, The Netherlands, 2017; pp. 242-262. [CrossRef]

53. Environmental Technology Centre. Biological Test Method: Reference Method for Determining the Toxicity of Sediment using Luminescent Bacteria in a Solid-Phase Test; Report EPS 1/RM/42; Environmental Technology Centre: Ottawa, ON, Canada, 2002; ISBN 0-660-18911-9.

54. ASTM (American Society for Testing and Materials). Standard Guide for Conducting Sediment Toxicity Tests with Luminescent Bacteria; Draft No. 8; ASTM: Philadelphia, PA, USA, 1995.

55. Panahi, H.K.S.; Dehhaghi, M.; Ok, Y.S.; Nizami, A.-S.; Khoshnevisan, B.; Mussatto, S.I.; Aghbashlo, M.; Tabatabaei, M.; Lam, S.S. A comprehensive review of engineered biochar: Production, characteristics, and environmental applications. J. Clean. Prod. 2020, 270, 122462. [CrossRef]

56. Zhao, B.; Xu, H.; Zhang, T.; Nan, X.; Ma, F. Effect of pyrolysis temperature on sulfur content, extractable fraction and release of sulfate in corn straw biochar. RSC Adv. 2018, 8, 35611-35617. [CrossRef]

57. Zheng, H.; Wang, Z.; Deng, X.; Zhao, J.; Luo, Y.; Novak, J.; Herbert, S.; Xing, B. Characteristics and nutrient values of biochars produced from giant reed at different temperatures. Bioresour. Technol. 2013, 130, 463-471. [CrossRef]

58. Cheah, S.; Malone, S.C.; Feik, C.J. Speciation of Sulfur in Biochar Produced from Pyrolysis and Gasification of Oak and Corn Stover. Environ. Sci. Technol. 2014, 48, 8474-8480. [CrossRef]

59. Palviainen, M.; Berninger, F.; Bruckman, V.J.; Köster, K.; de Assumpção, C.R.M.; Aaltonen, H.; Makita, N.; Mishra, A.; Kulmala, L.; Adamczyk, B.; et al. Effects of biochar on carbon and nitrogen fluxes in boreal forest soil. Plant Soil 2018, 425, 71-85. [CrossRef]

60. Cantrell, K.B.; Hunt, P.G.; Uchimiya, M.; Novak, J.M.; Ro, K. Impact of pyrolysis temperature and manure source on physicochemical characteristics of biochar. Bioresour. Technol. 2012, 107, 419-428. [CrossRef] [PubMed]

61. Nguyen, T.T.N.; Wallace, H.; Xu, C.-Y.; van Zwieten, L.; Weng, Z.H.; Xu, Z.; Che, R.; Tahmasbian, I.; Hu, H.-W.; Bai, S.H. The effects of short term, long term and reapplication of biochar on soil bacteria. Sci. Total Environ. 2018, 636, 142-151. [CrossRef] [PubMed]

62. Abujabhah, I.S.; Doyle, R.; Bound, S.A.; Bowman, J. The effect of biochar loading rates on soil fertility, soil biomass, potential nitrification, and soil community metabolic profiles in three different soils. J. Soils Sediments 2016, 16, 2211-2222. [CrossRef]

63. Agegnehu, G.; Nelson, P.; Bird, M.I. Crop yield, plant nutrient uptake and soil physicochemical properties under organic soil amendments and nitrogen fertilization on Nitisols. Soil Tillage Res. 2016, 160. [CrossRef]

64. Agegnehu, G.; Nelson, P.; Bird, M.I. The effects of biochar, compost and their mixture and nitrogen fertilizer on yield and nitrogen use efficiency of barley grown on a Nitisol in the highlands of Ethiopia. Sci. Total Environ. 2016, 569, 869-879. [CrossRef]

65. Agegnehu, G.; Bass, A.M.; Nelson, P.; Bird, M.I. Benefits of biochar, compost and biochar-compost for soil quality, maize yield and greenhouse gas emissions in a tropical agricultural soil. Sci. Total Environ. 2016, 543, 295-306. [CrossRef] [PubMed]

66. Prakongkep, N.; Gilkes, R.J.; Wiriyakitnateekul, W. Forms and solubility of plant nutrient elements in tropical plant waste biochars. J. Plant Nutr. Soil Sci. 2015, 178, 732-740. [CrossRef]

67. Hossain, Z.; Bahar, M.; Sarkar, B.; Donne, S.W.; Ok, Y.S.; Palansooriya, K.N.; Kirkham, M.B.; Chowdhury, S.; Bolan, N. Biochar and its importance on nutrient dynamics in soil and plant. Biochar 2020, 2, 379-420. [CrossRef]

68. Brennan, J.K.; Bandosz, T.J.; Thomson, K.T.; Gubbins, K.E. Water in porous carbons. Colloids Surfaces A Physicochem. Eng. Asp. 2001, 187, 539-568. [CrossRef]

69. Liu, G.; Li, S.; Cheng, M.; Zhao, L.; Zhang, B.; Gao, Y.; Xu, Y.; Liu, F.; Lu, G. Facile synthesis of nitrogen and sulfur co-doped carbon dots for multiple sensing capacities: Alkaline fluorescence enhancement effect, temperature sensing, and selective detection of $\mathrm{Fe}^{3+}$ ions. New J. Chem. 2018, 42, 13147-13156. [CrossRef]

70. Xu, Q.; Kuang, T.; Liu, Y.; Cai, L.; Peng, X.; Sreeprasad, T.S.; Zhao, P.; Yu, Z.; Li, N. Heteroatom-doped carbon dots: Synthesis, characterization, properties, photoluminescence mechanism and biological applications. J. Mater. Chem. B 2016, 4, 7204-7219. [CrossRef]

71. Suárez-Hernández, L.; Barrera-Zapata, R. Morphological and physicochemical characterization of biochar produced by gasification of selected forestry species. Rev. Fac. Ing. 2017, 26, 123-130. [CrossRef]

72. Shaaban, A.; Se, S.M.; Dimin, M.F.; Juoi, J.M.; Husin, M.H.M.; Mitan, N.M.M. Influence of heating temperature and holding time on biochars derived from rubber wood sawdust via slow pyrolysis. J. Anal. Appl. Pyrolysis. 2014, 107, 31-39. [CrossRef]

73. Zhao, S.X.; Ta, N.; Wang, X.D. Effect of temperature on the structural and physicochemical properties of biochar with apple tree branches as feedstock material. Energies 2017, 10, 1293. [CrossRef]

74. Gámiz, B.; Hall, K.; Spokas, K.A.; Cox, L. Understanding activation effects on low-temperature biochar for optimization of herbicide sorption. Agronomy 2019, 9, 588. [CrossRef]

75. Brewer, C.E. Biochar Characterization and Engineering. Ph.D. Thesis, Digital Repository, Iowa State University, Ames, IA, USA, 2012. [CrossRef]

76. Liu, Q.; Wang, S.; Zheng, Y.; Luo, Z.; Cen, K. Mechanism study of wood lignin pyrolysis by using TG-FTIR analysis. J. Anal. Appl. Pyrolysis. 2008, 82, 170-177. [CrossRef]

77. Yang, T.; Lua, A.C. Characteristics of activated carbons prepared from pistachio-nut shells by physical activation. J. Colloid Interface Sci. 2003, 267, 408-417. [CrossRef] 
78. Chemerys, V.; Baltrènaitè, E. Influence of Intrinsic Properties of Lignocellulosic Feedstock on Adsorptive Properties of Biochar. J. Environ. Eng. 2018, 144. [CrossRef]

79. Kołodyńska, D.; Bąk, J.; Kozioł, M.; Pylypchuk, L.V. Investigations of Heavy Metal Ion Sorption Using Nanocomposites of Iron-Modified Biochar. Nanoscale Res. Lett. 2017, 12. [CrossRef]

80. Jouiad, M.; Al-Nofeli, N.; Khalifa, N.; Benyettou, F.; Yousef, L.F. Characteristics of slow pyrolysis biochars produced from rhodes grass and fronds of edible date palm. J. Anal. Appl. Pyrolysis. 2015, 111, 183-190. [CrossRef]

81. Tang, Y.; Alam, M.S.; Konhauser, K.O.; Alessi, D.S.; Xu, S.; Tian, W.J.; Liu, Y. Influence of pyrolysis temperature on production of digested sludge biochar and its application for ammonium removal from municipal wastewater. J. Clean. Prod. 2019, 209, 927-936. [CrossRef]

82. Zuo, P.; Lu, X.; Sun, Z.; Guo, Y.; He, H. A review on syntheses, properties, characterization and bioanalytical applications of fluorescent carbon dots. Microchim. Acta 2016, 183, 519-542. [CrossRef]

83. Mei, S.; Wei, X.; Hu, Z.; Wei, C.; Su, D.; Yang, D.; Zhang, G.; Zhang, W.; Guo, R. Amphipathic carbon dots with solvent-dependent optical properties and sensing application. Opt. Mater. 2019, 89, 224-230. [CrossRef]

84. Wei, X.; Mei, S.; Yang, D.; Zhang, G.; Xie, F.; Zhang, W.; Guo, R. Surface States Induced Photoluminescence Enhancement of Nitrogen-Doped Carbon Dots via Post-Treatments. Nanoscale Res. Lett. 2019, 14, 172. [CrossRef]

85. Chao, D.; Lyu, W.; Liu, Y.; Zhou, L.; Zhang, Q.; Deng, R.; Zhang, H. Solvent-dependent carbon dots and their applications in the detection of water in organic solvents. J. Mater. Chem. C 2018, 6, 7527-7532. [CrossRef]

86. Zhang, L.; Liu, W.; Zhuang, H.; Zhang, J.; Chen, C.; Wang, Y.; Shan, S. Environmentally friendly synthesis of photoluminescent biochar dots from waste soy residues for rapid monitoring of potentially toxic elements. RSC Adv. 2019, 9, 21653-21659. [CrossRef]

87. Prekodravac, J.; Vasiljević, B.; Marković, Z.; Jovanović, D.; Kleut, D.; Špitalský, Z.; Mičušik, M.; Danko, M.; Bajuk-Bogdanović, D.; Todorović-Marković, B. Green and facile microwave assisted synthesis of (metal-free) N-doped carbon quantum dots for catalytic applications. Ceram. Int. 2019, 45, 17006-17013. [CrossRef]

88. Ju, J.; Zhang, R.; He, S.; Chen, W. Nitrogen-doped graphene quantum dots-based fluorescent probe for the sensitive turn-on detection of glutathione and its cellular imaging. RSC Adv. 2014, 4, 52583-52589. [CrossRef]

89. Villanueva, F.Y.; Manioudakis, J.; Naccache, R.; Majewski, M.B. Carbon Dot-Sensitized Photoanodes for Visible Light-Driven Organic Transformations. ACS Appl. Nano Mater. 2020, 3, 2756-2765. [CrossRef]

90. Dastidar, D.G.; Mukherjee, P.; Ghosh, D.; Banerjee, D. Carbon quantum dots prepared from onion extract as fluorescence turn-on probes for selective estimation of $\mathrm{Zn}^{2+}$ in blood plasma. Colloids Surfaces A Physicochem. Eng. Asp. 2021, 611, 125781. [CrossRef]

91. Dager, A.; Uchida, T.; Maekawa, T.; Tachibana, M. Synthesis and characterization of Mono-disperse Carbon Quantum Dots from Fennel Seeds: Photoluminescence analysis using Machine Learning. Sci. Rep. 2019, 9. [CrossRef] [PubMed]

92. Tुucureanu, V.; Matei, A.; Avram, A.M. FTIR Spectroscopy for Carbon Family Study. Crit. Rev. Anal. Chem. 2016, 46, 502-520. [CrossRef]

93. Kuo, T.R.; Sung, S.Y.; Hsu, C.W.; Chang, C.J.; Chiu, T.C.; Hu, C.C. One-pot green hydrothermal synthesis of fluorescent nitrogen-doped carbon nanodots for in vivo bioimaging. Anal. Bioanal. Chem. 2016, 408, 77-82. [CrossRef] [PubMed]

94. Pham-Truong, T.N.; Ranjan, C.; Randriamahazaka, H.; Ghilane, J. Nitrogen doped carbon dots embedded in poly(ionic liquid) as high efficient metal-free electrocatalyst for oxygen reduction reaction. Catal. Today 2019, 335, 381-387. [CrossRef]

95. Mehta, V.N.; Jha, S.; Kumar, S. One-pot green synthesis of carbon dots by using Saccharum of fi cinarum juice for fl uorescent imaging of bacteria (Escherichia coli) and yeast (Saccharomyces cerevisiae) cells. Mater. Sci. Eng. C 2014, 38, 20-27. [CrossRef]

96. Thambiraj, S.; Shankaran, D.R. Green synthesis of highly fluorescent carbon quantum dots from sugarcane bagasse pulp. Appl. Surf. Sci. 2016, 390, 435-443. [CrossRef]

97. Liu, H.; He, Z.; Jiang, L.P.; Zhu, J.J. Microwave-assisted synthesis of wavelength-tunable photoluminescent carbon nanodots and their potential applications. ACS Appl. Mater. Interfaces 2015, 7, 4913-4920. [CrossRef] [PubMed]

98. Liu, M.L.; Yang, L.; Li, R.S.; Chen, B.B.; Liu, H.; Huang, C.Z. Large-scale simultaneous synthesis of highly photoluminescent green amorphous carbon nanodots and yellow crystalline graphene quantum dots at room temperature. Green Chem. 2017, 19, 3611-3617. [CrossRef]

99. Zhu, S.; Meng, Q.; Wang, L.; Zhang, J.; Song, Y.; Jin, H.; Zhang, K.; Sun, H.; Wang, H.; Yang, B. Highly photoluminescent carbon dots for multicolor patterning, sensors, and bioimaging. Angew. Chem. Int. Ed. 2013, 52, 3953-3957. [CrossRef] [PubMed]

100. Shen, D.; Long, Y.; Wang, J.; Yu, Y.; Pi, J.; Yang, L.; Zheng, H. Tuning the fluorescence performance of carbon dots with a reduction pathway. Nanoscale 2019, 11, 5998-6003. [CrossRef]

101. Zhang, Y.; Yuan, R.; He, M.; Hu, G.; Jiang, J.; Xu, T.; Zhou, L.; Chen, W.; Xiang, W.; Liang, X. Multicolour nitrogen-doped carbon dots: Tunable photoluminescence and sandwich fluorescent glass-based light-emitting diodes. Nanoscale 2017, 9, 17849-17858. [CrossRef] [PubMed]

102. Wang, L.; Zhu, S.J.; Wang, H.Y.; Qu, S.N.; Zhang, Y.L.; Zhang, J.H.; Chen, Q.D.; Xu, H.L.; Han, W.; Yang, B.; et al. Common origin of green luminescence in carbon nanodots and graphene quantum dots. ACS Nano 2014, 8, 2541-2547. [CrossRef] [PubMed]

103. Moradi, S.; Sadrjavadi, K.; Farhadian, N.; Hosseinzadeh, L.; Shahlaei, M. Easy synthesis, characterization and cell cytotoxicity of green nano carbon dots using hydrothermal carbonization of Gum Tragacanth and chitosan bio-polymers for bioimaging. J. Mol. Liq. 2018, 259, 284-290. [CrossRef]

104. Zhang, Q.; Xie, S.; Yang, Y.; Wu, Y.; Wang, X.; Wu, J.; Zhang, L.; Chen, J.; Wang, Y. A facile synthesis of highly nitrogen-doped carbon dots for imaging and detection in biological samples. J. Anal. Methods Chem. 2018, 2018. [CrossRef] 
105. Zhang, J.; Yang, L.; Yuan, Y.; Jiang, J.; Yu, S.H. One-Pot Gram-Scale Synthesis of Nitrogen and Sulfur Embedded Organic Dots with Distinctive Fluorescence Behaviors in Free and Aggregated States. Chem. Mater. 2016, 28, 4367-4374. [CrossRef]

106. Chen, W.; Li, D.; Tian, L.; Xiang, W.; Wang, T.; Hu, W.; Hu, Y.; Chen, S.; Chen, J.; Dai, Z. Synthesis of graphene quantum dots from natural polymer starch for cell imaging. Green Chem. 2018, 20, 4438-4442. [CrossRef]

107. Ramanan, V.; Thiyagarajan, S.K.; Raji, K.; Suresh, R.; Sekar, R.; Ramamurthy, P. Outright green synthesis of fluorescent carbon dots from eutrophic algal blooms for in vitro imaging. ACS Sustain. Chem. Eng. 2016, 4, 4724-4731. [CrossRef]

108. Zhang, J.; Liu, X.; Zhou, J.; Huang, X.; Xie, D.; Ni, J.; Ni, C. Carbon dots derived from algae as $\mathrm{H}_{2} \mathrm{O}_{2}$ sensors: The importance of nutrients in biomass. Nanoscale Adv. 2019, 1, 2151-2156. [CrossRef]

109. Liu, H.; Li, Z.; Sun, Y.; Geng, X.; Hu, Y.; Meng, H.; Ge, J.; Qu, L. Synthesis of Luminescent Carbon Dots with Ultrahigh Quantum Yield and Inherent Folate Receptor-Positive Cancer Cell Targetability. Sci. Rep. 2018, 8. [CrossRef]

110. Shen, L.; Zhang, L.; Chen, M.; Chen, X.; Wang, J. The production of $\mathrm{pH}$-sensitive photoluminescent carbon nanoparticles by the carbonization of polyethylenimine and their use for bioimaging. Carbon 2013, 55, 343-349. [CrossRef]

111. Wang, S.; Niu, H.; He, S.; Cai, Y. One-step fabrication of high quantum yield sulfur- and nitrogen-doped carbon dots for sensitive and selective detection of Cr(vi). RSC Adv. 2016, 6, 107717-107722. [CrossRef]

112. Huang, Q.; Li, Q.; Chen, Y.; Tong, L.; Lin, X.; Zhu, J.; Tong, Q. High quantum yield nitrogen-doped carbon dots: Green synthesis and application as "off-on" fluorescent sensors for the determination of $\mathrm{Fe}^{3+}$ and adenosine triphosphate in biological samples. Sensors Actuators B Chem. 2018, 276, 82-88. [CrossRef]

113. Li, M.; Yu, C.; Hu, C.; Yang, W.; Zhao, C.; Wang, S.; Zhang, M.; Zhao, J.; Wang, X.; Qiu, J. Solvothermal conversion of coal into nitrogen-doped carbon dots with singlet oxygen generation and high quantum yield. Chem. Eng. J. 2017, 320, 570-575. [CrossRef]

114. Wang, Y.; Xia, Y. Optical, electrochemical and catalytic methods for in-vitro diagnosis using carbonaceous nanoparticles: A review. Microchim. Acta 2019, 186, 50. [CrossRef]

115. Xu, Q.; Li, B.; Ye, Y.; Cai, W.; Li, W.; Yang, C.; Chen, Y.; Xu, M.; Li, N.; Zheng, X.; et al. Synthesis, mechanical investigation, and application of nitrogen and phosphorus co-doped carbon dots with a high photoluminescent quantum yield. Nano Res. 2018, 11, 3691-3701. [CrossRef]

116. Dong, Y.; Pang, H.; Bin Yang, H.; Guo, C.; Shao, J.; Chi, Y.; Li, C.M.; Yu, T. Carbon-Based Dots Co-doped with Nitrogen and Sulfur for High Quantum Yield and Excitation-Independent Emission. Angew. Chem. Int. Ed. 2013, 52, 7800-7804. [CrossRef]

117. Ding, H.; Wei, J.-S.; Xiong, H.-M. Nitrogen and sulfur co-doped carbon dots with strong blue luminescence. Nanoscale 2014, 6, 13817-13823. [CrossRef] [PubMed]

118. Qin, X.; Lu, W.; Asiri, A.M.; Al-Youbi, A.O.; Sun, X. Green, low-cost synthesis of photoluminescent carbon dots by hydrothermal treatment of willow bark and their application as an effective photocatalyst for fabricating Au nanoparticles-reduced graphene oxide nanocomposites for glucose detection. Catal. Sci. Technol. 2013, 3, 1027. [CrossRef]

119. Lu, W.; Qin, X.; Liu, S.; Chang, G.; Zhang, Y.; Luo, Y.; Asiri, A.M.; Al-Youbi, A.O.; Sun, X. Economical, Green Synthesis of Fluorescent Carbon Nanoparticles and Their Use as Probes for Sensitive and Selective Detection of Mercury(II) Ions. Anal. Chem. 2012, 84, 5351-5357. [CrossRef] [PubMed]

120. Zhao, X.J.; Zhang, W.L.; Zhou, Z.Q. Sodium hydroxide-mediated hydrogel of citrus pectin for preparation of fluorescent carbon dots for bioimaging. Colloids Surfaces B Biointerfaces 2014, 123, 493-497. [CrossRef] [PubMed]

121. Feng, X.; Jiang, Y.; Zhao, J.; Miao, M.; Cao, S.; Fang, J.; Shi, L. Easy synthesis of photoluminescent N-doped carbon dots from winter melon for bio-imaging. RSC Adv. 2015, 5, 31250-31254. [CrossRef]

122. Hsu, P.-C.; Shih, Z.-Y.; Lee, C.-H.; Chang, H.-T. Synthesis and analytical applications of photoluminescent carbon nanodots. Green Chem. 2012, 14, 917-920. [CrossRef]

123. Niemirycz, E.; Nichthauser, J.; Staniszewska, M.; Nałęcz-Jawecki, G.; Bolałek, J. The Microtox ${ }^{\circledR}$ biological test: Application in toxicity evaluation of surface waters and sediments in Poland. Oceanol. Hydrobiol. Stud. 2007, 36, 151-163. [CrossRef]

124. EPA's Science Policy Council. Nanotechnology White Paper. EPA 100/B-07/001; EPA's Science Policy Council: Washington, DC, USA, 2007. Available online: www.epa.gov / osa (accessed on 11 June 2021).

125. Savolainen, K.; Backman, U.; Brouwer, D.; Fadeel, B.; Fernandes, T.; Kuhlbusch, T.; Landsiedel, R.; Lynch, I.; Pylkkanen, L. Nanosafety in Europe 2015-2025: Towards Safe and Sustainable Nanomaterials and Nanotechnology Innovations; Finnish Institute of Occupational Health: Helsinki, Finland, 2013.

126. Saleh, T.A. Nanomaterials: Classification, properties, and environmental toxicities. Environ. Technol. Innov. 2020, $20,101067$. [CrossRef]

127. Alas, M.O.; Alkas, F.B.; Sukuroglu, A.A.; Alturk, R.G.; Battal, D. Fluorescent carbon dots are the new quantum dots: An overview of their potential in emerging technologies and nanosafety. J. Mater. Sci. 2020, 55, 15074-15105. [CrossRef]

128. Yao, K.; Lv, X.; Zheng, G.; Chen, Z.; Jiang, Y.; Zhu, X.; Wang, Z.; Cai, Z. Effects of Carbon Quantum Dots on Aquatic Environments: Comparison of Toxicity to Organisms at Different Trophic Levels. Environ. Sci. Technol. 2018, 52, 14445-14451. [CrossRef] 